\title{
Loss of Sensitivity to EDTA by Pseudomonas aeruginosa Grown under Conditions of Mg-Limitation
}

\author{
By M. R. W. BROWN AND J. MELLING \\ Pharmaceutical Microbiology Group, School of Pharmacy, Bath \\ University of Technology, Bath, Somerset \\ (Accepted for publication 8 August I968)

\begin{abstract}
SUMMARY
Pseudomonas aeruginosa was grown in batch culture in simple salts medium under conditions of $\mathrm{Mg}$-limitation and varying degrees of $\mathrm{Mg}$ excess. Sensitivity to EDTA was measured in terms of lysis and decrease in colony count. The greater the degree of $\mathrm{Mg}$-limitation the greater was the resistance to loss of viability and lysis. Loss of viability of sensitive bacteria occurred more rapidly than lysis. This suggests that bacterial death preceded cell lysis.
\end{abstract}

\section{INTRODUCTION}

EDTA has been shown to render Gram-negative bacteria sensitive to the action of lysozyme and it has been suggested that EDTA increases the permeability of the outer layers of the cell wall, allowing lysozyme to penetrate to the underlying mucopeptide layer (Costerton et al. 1967). Treatment of Gram-negative organisms with EDTA has been shown to result in lysis, loss of viability and release of substances absorbing at $260 \mathrm{~m} \mu$ (Gray \& Wilkinson, $1965 a$; Neu, 1966) and to increased sensitivity to a variety of antibacterial agents (Brown \& Richards, 1965; Leive, 1965). The degree of sensitivity of Gram-negative organisms has been shown by Wilkinson (I967) to vary between species. Gray \& Wilkinson $(1965 b)$ found that this sensitivity was related to the ability of EDTA to solubilize components of isolated cell walls of the particular organism and they concluded that the lipopolysaccharide portion was probably involved. The presence of divalent cations in the cell walls of Pseudomonas aeruginosa has been demonstrated (Eagon, Simmons \& Carson, I965), and Asbell \& Eagon (1966) suggested that EDTA acted by chelating cations involved in cross-linkages with lipopolysaccharide components of the cell wall. Costerton et al. (1967) suggested that $\mathrm{Mg}$ might be one of the cations involved. The object of the present work was to determine the sensitivity to EDTA of $P$. aeruginosa organisms grown with various $\mathrm{Mg}$ concentrations. To avoid changes in sensitivity due to washing procedure (Brown, 1968), unwashed cultures were used.

\section{METHODS}

Organism. Pseudomonas aeruginosa NCTC 6750 was used throughout this study.

Chemicals. All chemicals used were of AnalarR grade.

Cleaning procedures. All glass-ware was treated with sulphuric + chromic acid mixture, washed with tap water and finally in glass-distilled water.

Culture methods. The culture was maintained in a liquid medium without added $\mathrm{Mg}$ 
which consisted of: $0.00 \mathrm{I} \mathrm{M-D}(+)$ glucose, 0.0I M- $\left(\mathrm{NH}_{4}\right)_{2} \mathrm{HPO}_{4}$, 0.0I M- $\left(\mathrm{NH}_{4}\right)_{2} \mathrm{SO}_{4}$, $0.0005 \mathrm{M}-\mathrm{NaCl}, 0.0005 \mathrm{M}-\mathrm{KCl}$ dissolved in glass-distilled water $(\mathrm{pH} 7 \cdot 3)$. Bacteria used in the following experiments were grown in media identical to the above, but containing graded concentrations of $\mathrm{MgSO}_{4}$. Cultures $(500 \mathrm{ml}$.) were grown in 21 . flasks in a Mickle shaker bath (The Mickle Laboratory Engineering Co. Gomshall, Surrey) at $37.5^{\circ}$. The growth rate was initially the same in all cultures but became increasingly decreased because of $\mathrm{Mg}$ limitation. Cultures with the lower concentrations of $\mathrm{Mg}$ showed the greater degree of $\mathrm{Mg}$ limitation of growth. Cell division eventually ceased owing to depletion of glucose at an extinction $(E)$ of about $0 \cdot 180$ measured at $470 \mathrm{~m} \mu$ by using a Unicam SP 600 spectrophotometer. This corresponded to a colony count of about $3.5 \times 10^{8}$ bacteria $/ \mathrm{ml}$. Unwashed cultures in this condition were used for all studies with EDTA and were taken for treatment when the $E_{470}$ value had remained constant for $\mathrm{I} \mathrm{hr}$. The growth medium was at $\mathrm{pH} 7 \cdot 3$ at inoculation and decreased to $7 \cdot 2$ by the time cell division ceased. This $\mathrm{pH}$ value was unaltered by the EDTA treatments used.

Treatment of bacteria with EDTA. Samples $\left(93 \mathrm{ml}\right.$.) of unwashed culture at $37.5^{\circ}$ were added to $7 \mathrm{ml}$. volumes of EDTA solutions of various concentrations in $250 \mathrm{ml}$. flasks in a water bath at $37.5^{\circ}$. The EDTA treated cultures ( $\mathrm{pH} 7 \cdot 2$ ) were maintained at $37.5^{\circ}$ throughout the experimental period.

Measurement of lysis. Samples ( $3 \mathrm{ml}$.) of EDTA-treated cultures were taken and the extinction of the sample measured at $470 \mathrm{~m} \mu\left(E_{470}\right)$.

Colony count estimations. Samples (I ml.) of EDTA-treated bacteria were removed and after inactivation of the EDTA by dilution in nutrient broth (Oxoid) to which $\mathrm{CaCl}_{2}$ was added, $0.5 \mathrm{ml}$. volumes were spread on surface-dried nutrient agar plates. Colonies were counted after incubation for $36 \mathrm{hr}$ at $37^{\circ} 5^{\circ}$.

\section{RESULTS}

Preliminary experiments indicated a definite $\mathrm{Mg}$ requirement for growth by $P$ seudomonas aeruginosa. This accords with the findings of other workers (Webb, I949) and of Tempest, Hunter \& Sykes (1965) who showed Mg to be an essential component of the ribosomes of Aerobacter aerogenes. Figure I illustrates representative results of growing pseudomonads in the basal medium with the addition of graded amounts of $\mathrm{Mg}$. The lag period was inversely proportional to the $\mathrm{Mg}$ concentration originally in the medium. Cell division did not cease abruptly as $\mathrm{Mg}$ became limiting, but progressively slowed. This finding was in agreement with that of Tempest et al. (1965). Eventually cell division ceased in all cultures owing to depletion of glucose, but at the lower $\mathrm{Mg}$ concentrations the final extinction value was lower than that attained by cultures containing higher concentrations of $\mathrm{Mg}$. Presumably during the period of slower growth (depending on $\mathrm{Mg}$ concentration) glucose was depleted by cell respiration. $\mathrm{Mg}$ concentrations were selected such that, although at the lowest concentrations $\mathrm{Mg}$ limitation of growth had occurred, the final $E_{\mathbf{4 7 0}}$ value was close to the maximum possible for the glucose concentration ( $0.001 \mathrm{M}$ in every case).

\section{Effect of Mg-limitation on lysis of Pseudomonas aeruginosa by EDTA}

Suspensions of bacteria were taken for EDTA treatment when the $E_{470}$ value had remained constant for $\mathrm{I} \mathrm{hr}$. Lysis of bacteria grown in the basal medium with the 
addition of $\mathrm{Mg}$ I $\mu \mathrm{g}$. $/ \mathrm{ml}$. resulted after treatment with various EDTA concentrations (Fig. 2). This procedure was repeated with bacteria grown in a range of $\mathrm{Mg}$ concentrations and the decrease in $E_{470}$ value after $180 \mathrm{~min}$. taken as a measure of sensitivity.

Figure 3 illustrates the effectiveness of several EDTA concentrations in causing lysis, measured for bacteria grown in $0.05,0 \cdot 2,0 \cdot 5, \mathrm{I} \cdot 0,2 \cdot 0$ and $4 \cdot 0 \mu \mathrm{g}$. Mg/ml. Two distinct

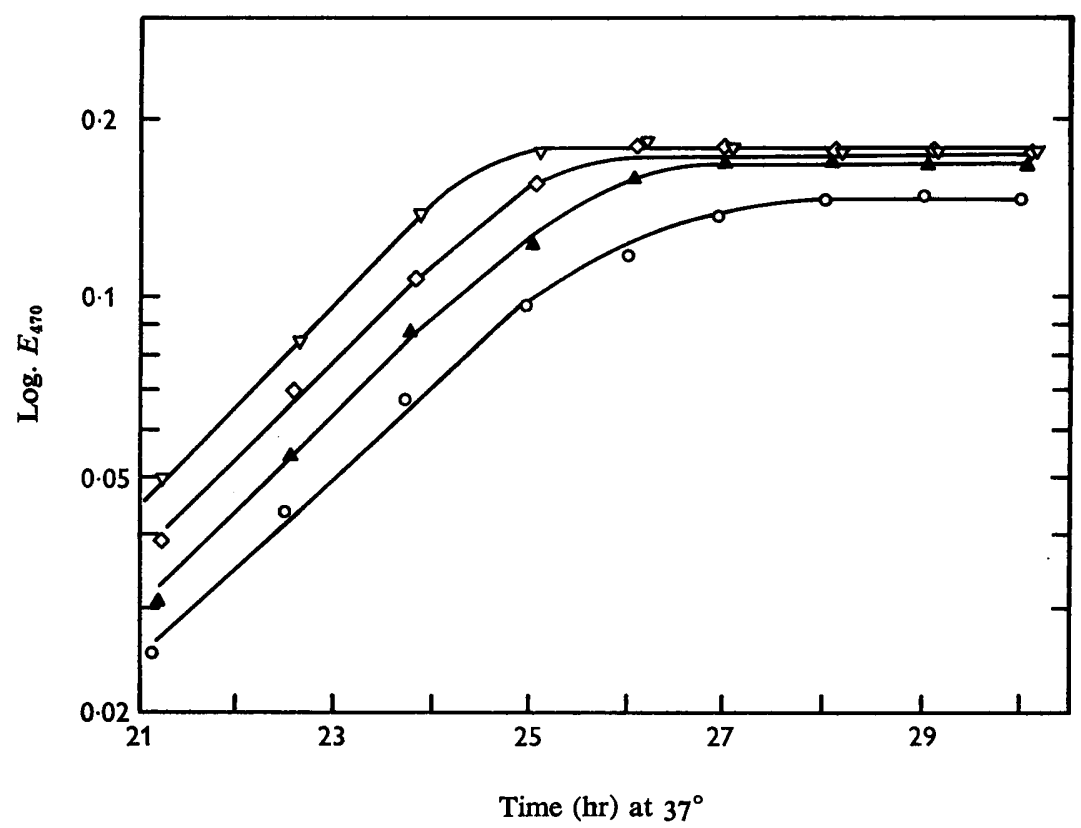

Fig. I. Effect of magnesium content of medium on growth of Pseudomonas aerugionosa. $\mathrm{Mg}$ concentrations $(\mu \mathrm{g} . / \mathrm{ml}$.$) were: 0,0.05 ; \Delta, 0.1 ; \diamond, 0.45 ; \nabla, \mathrm{I}$.
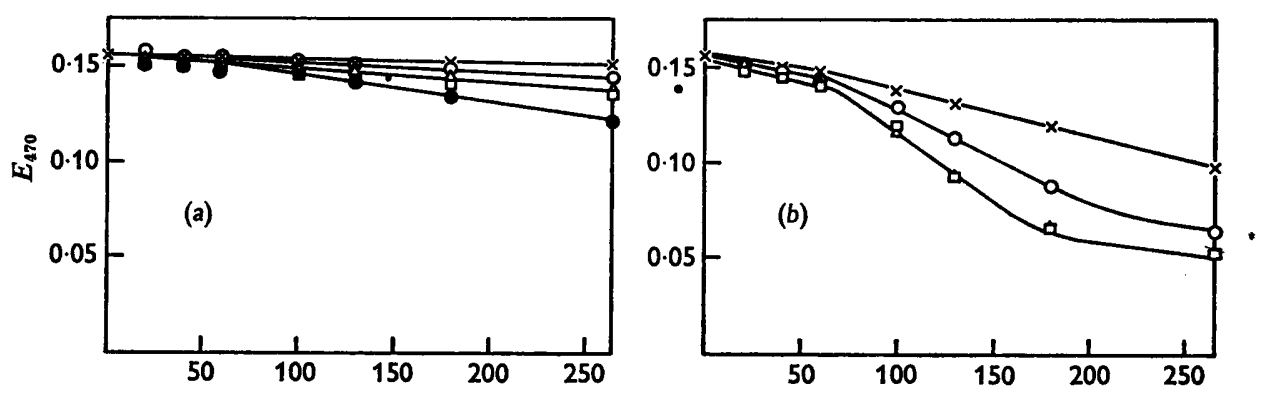

Time (min.)

Fig. 2. Effect of EDTA concentration on lysis of Pseudomonas aeruginosa grown in medium with I $\mu \mathrm{g} . \mathrm{Mg} / \mathrm{ml}$. Bacteria not $\mathrm{Mg}$-limited. EDTA concentrations $(\mu \mathrm{g} . / \mathrm{ml}$.) were- $(a): \times$, zero; $O, 10 ; \triangle, 20 ; \square, 25 ; 0,37 \cdot 5 ;$ and $(b): \times, 50 ; 0,100 ; \triangle, 375 ; \square, 1000$.

effects were observable. First, as the EDTA concentration was increased the rate of lysis increased to a maximum for bacteria grown in any one $\mathrm{Mg}$ concentration. The EDTA concentration required to produce a maximum effect was greater, the higher 


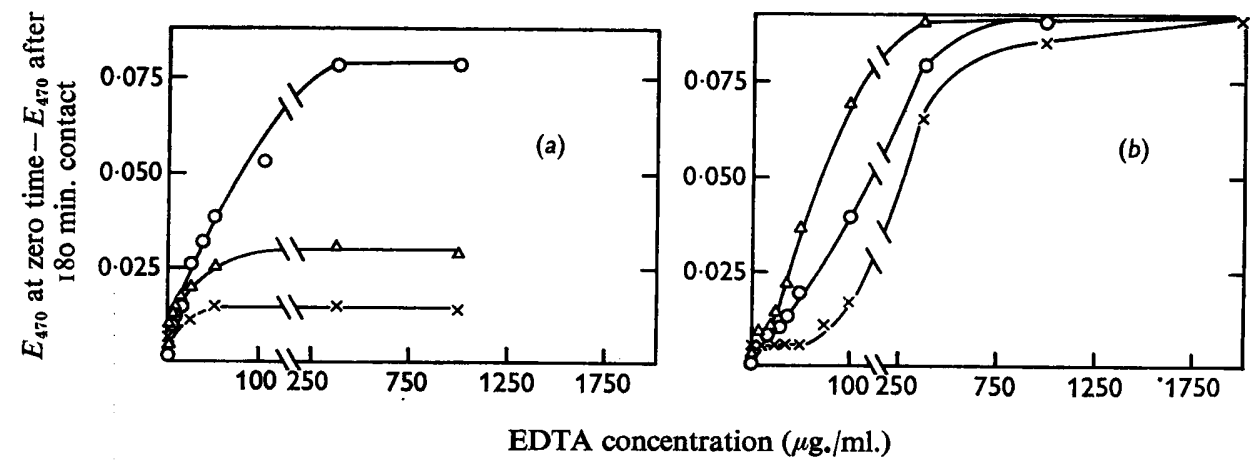

Fig. 3. Effect of EDTA concentration on rate of lysis of Pseudomonas aeruginosa grown in media with different $\mathrm{Mg}$ concentrations. $\mathrm{Mg}$ concentrations $(\mu \mathrm{g} . / \mathrm{ml}$.$) were -(a): 0,0.5$; $\triangle, 0.2 ; \times, 0.05$ and $(b): \times, 4 ; 0,2 ; \triangle, I$.

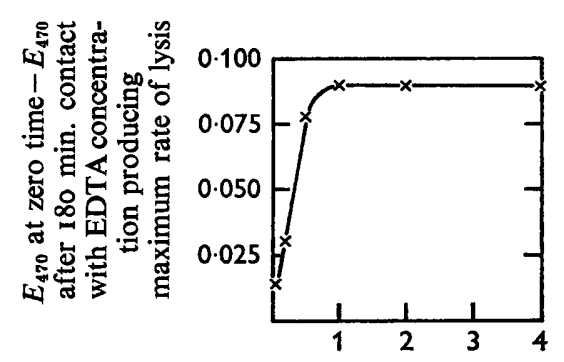

$\mathrm{Mg}$ concentration of medium $(\mu \mathrm{g} . / \mathrm{ml}$.)

Fig. 4

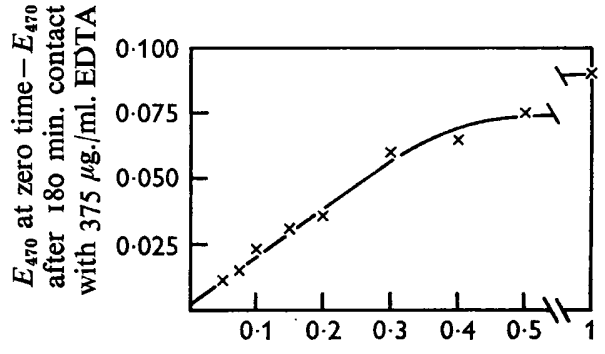

Mg concentration of medium ( $\mu \mathrm{g} . / \mathrm{ml}$.

Fig. 5

Fig. 4. Maximum rate of lysis by EDTA of Pseudomonas aeruginosa grown in media with different $\mathrm{Mg}$ concentrations. Maximum rate of lysis at any one $\mathrm{Mg}$ concentration can be deduced from Fig. 3.

Fig. 5. Relationship between maximum rate of lysis of Pseudomonas aeruginosa by EDTA and $\mathrm{Mg}$ concentration in the medium. $375 \mu \mathrm{g}$. EDTA $/ \mathrm{ml}$. produced maximum rate of lysis over this $\mathrm{Mg}$ range.

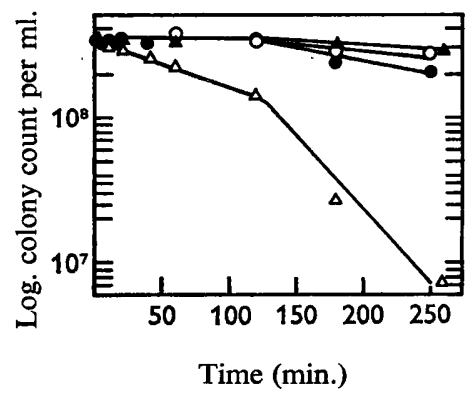

Fig. 6. Effect of EDTA $375 \mu \mathrm{g} . / \mathrm{ml}$. on the colony count of Pseudomonas aeruginosa grown in a basal medium with different $\mathrm{Mg}$ concentrations. $0,0.05 \mu \mathrm{g} . \mathrm{Mg} . / \mathrm{ml}$. untreated;, $0.05 \mathrm{Mg}$. $\mu \mathrm{g} . / \mathrm{ml}$. treated with $375 \mu \mathrm{g} . / \mathrm{ml}$. EDTA; $\Delta, \mathbf{1} \mu \mathrm{g} . \mathrm{Mg} / \mathrm{ml}$. untreated; $\Delta$, I $\mu \mathrm{g} . \mathrm{Mg} / \mathrm{ml}$. treated with $375 \mu \mathrm{g}$. EDTA/ml. 
the $\mathrm{Mg}$ concentration in the growth medium. This agrees with earlier work which showed that cations in excess of growth requirements reduced the activity of EDTA against unwashed bacteria (Brown \& Richards, 1965). Secondly, over the range of $\mathbf{M g}$ concentrations 0.05 to $0.5 \mu \mathrm{g}$. $/ \mathrm{ml}$. a large change in maximum rate of lysis occurred, while further increases in the $\mathrm{Mg}$ concentrations produced only a small increase in the maximum rate of lysis (Fig. 4). To investigate this phenomenon further, bacteria grown in $\mathrm{Mg}$ concentrations over the range 0.05 to $0.5 \mu \mathrm{g} . / \mathrm{ml}$. were treated with $375 \mu \mathrm{g}$. EDTA/ml, a concentration shown to produce maximum rate of lysis over this range of $\mathrm{Mg}$ concentrations. The results (Fig. 5) indicated a linear relationship between the maximum rate of lysis and the concentration of $\mathrm{Mg}$ in the growth medium below about $0.3 \mu \mathrm{g} . / \mathrm{ml}$.

\section{Effect of EDTA on viable counts of Mg-limited cultures}

Colony counts were made at intervals upon bacteria grown in (a) I $\mu \mathrm{g} . \mathrm{Mg} / \mathrm{ml}$., (b) $0.05 \mu \mathrm{g} . \mathrm{Mg} / \mathrm{ml}$, which had been treated with $375 \mu \mathrm{g}$. EDTA $/ \mathrm{ml}$. The results (Fig. 6) indicated once again that bacteria grown in the low $\mathrm{Mg}$ concentration were much more resistant to EDTA than bacteria produced in the high concentration. After $250 \mathrm{~min}$. the colony count of the Mg-limited bacteria had decreased about $25 \%$, whereas the bacteria not $\mathrm{Mg}$-limited had a decrease in colony count of about 40-fold. Comparison of these data with details of lysis resulting from EDTA treatment indicated that loss of viability proceeded more rapidly than lysis. This suggested that bacterial death preceded cell lysis.

\section{DISCUSSION}

It has been suggested that EDTA acts by removal of divalent cations, probably $\mathrm{Ca}$ or $\mathrm{Mg}$, from the cell wall of Pseudomonas aeruginosa where these ions occupy positions of structural importance (Asbell \& Eagon, 1966). The present results support this concept. Calcium was not added to the medium used in this study and any traces present would have been impurities of the Analar chemicals. In fact, the basal medium contained $0.06 \mu \mathrm{g}$. $\mathrm{Ca} / \mathrm{ml}$. impurity as determined by flame photometry (Unicam $\mathrm{SP}$ 900). The fact that the bacteria grown in the lowest $\mathrm{Mg}$ concentration were almost completely resistant to the action of EDTA may have been due to a lack of such cations in the cell-wall architecture. The linear relationship between lysis and $\mathrm{Mg}$ concentration in the growth medium probably reflected a relationship between $\mathrm{Mg}$ in the medium and the wall structure of the eventual $\mathrm{Mg}$-limited cells. It may also be that, as in the case of Aerobacter aerogenes, the organic components of the cell wall differed when the bacteria were deprived of $\mathrm{Mg}$ (Ellwood \& Tempest, 1967). The above findings indicated that the use of EDTA in classification of pseudomonads (Wilkinson, 1967) must be approached with caution since more or less $\mathrm{Mg}$ in the growth medium could greatly affect the result. The effect of $\mathrm{Mg}$ in the growth medium may also be important where spheroplast or protoplast production involves EDTA treatment.

We thank the Medical Research Council for a grant which supported part of this work. 


\section{REFERENCES}

AsBell, M. A. \& EAGON, R. G. (1966). Role of multivalent cations in the organization, structure and assembly of the cell wall of Pseudomonas aeruginosa. J. Bact. 92, 380.

BRown, M. R. W. (1968). Survival of Pseudomonas aeruginosa in fluorescein solution: preservative action of PMN and EDTA. J. Pharm. Sci. 57, 389.

BRown, M. R. W. \& RICHARDS, R. M. E. (1965). The effect of EDTA on the resistance of Pseudomonas aeruginosa to antibacterial agents. Nature, Lond. 207, 1391.

Costerton, J. W., Forsberg, C., Matula, T. I., Buckmire, L. A. \& Macleod, R. A. (1967). Nutrition and metabolism of marine bacteria. XVI. Formation of protoplasts, spheroplasts and related forms from a Gram-negative marine bacterium. J. Bact. 94, 1764.

Eagon, R. G., Simmons, G. P. \& Carson, K. J. (1965). Evidence for the presence of ash and divalent metals in the cell wall of Pseudomonas aeruginosa. Can. J. Microbiol. II, I04I.

Ellwood, D. C. \& TEMPEST, D. W. (1967). Influence of growth conditions on the cell wall content and wall composition of Aerobacter aerogenes. Biochem. J. 105, 9 P..

GraY, G. W. \& WIIKInson, S. G. (1965a). The action of EDTA on Pseudomonas aeruginosa. J. appl. Bact. 28, 153.

GraY, G. W. \& WhKINSON, S. G. (1965b). The effect of ethylenediaminetetra-acetic acid on the cell walls of some gram-negative bacteria. J. gen. Microbiol. 39, 385.

Lerve, L. (1965). Actinomycin sensitivity in Escherichia coli. Bochem. biophys. Res. Commun. I8, I 3.

NeU, H. C. (1966). The release of the acid soluble nucleotide pool of Escherichia coli by EDTA-tris. Biochem. biophys. Res. Commun. 25, 615.

Tempest, D. W., HunTER, J. R. \& SYKes, J. (1965). Magnesium-limited growth of Aerobacter aerogenes in a chemostat. J. gen. Microbiol. 39, 355.

WeBB, M. (1949). The influence of magnesium on cell division (3). The effect of magnesium on the growth of bacteria in simple chemically defined media. J. gen. Microbiol. 3, 418.

WIIKINSON, S. G. (1967). The sensitivity of pseudomonads to ethylenediaminetetra-acetic acid. J. gen. Microbiol. 47, 67. 